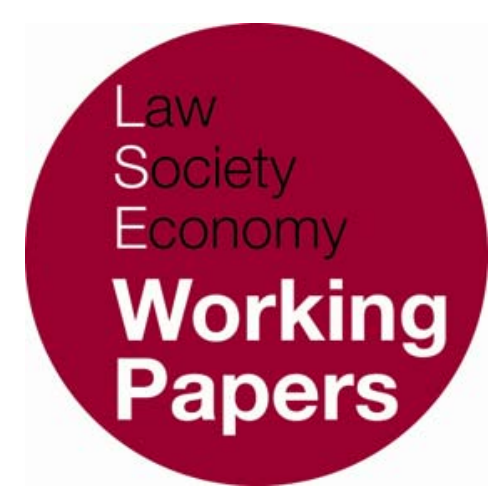

\title{
Utility and Rights in Common Law Reasoning: Rebalancing Private Law Through Constitutionalization
}

\author{
Hugh Collins
}

LSE Law, Society and Economy Working Papers 6/2007

London School of Economics and Political Science

Law Department

This paper can be downloaded without charge from LSE Law, Society and Economy

Working Papers at: www.lse.ac.uk/collections/law/wps/wps.htm and the Social Science Research Network electronic library at: http:/ / ssrn.comabstract $=1011727$

(C) Hugh Collins. Users may download and/or print one copy to facilitate their private study or for non-commercial research. Users may not engage in further distribution of this material or use it for any profit-making activities or any other form of commercial gain. 


\title{
Utility and Rights in Common Law Reasoning: Rebalancing Private Law Through Constitutionalization
}

\author{
Hugh Collins ${ }^{*}$
}

\begin{abstract}
In the evolution of private law, legal reasoning has always confronted the fundamental problem of reconciling private interests with collective goods. Philosophers analyse this problem of justice in terms of protecting individual rights whilst at the same time maximizing utility or general welfare. The private law of tort, contract, and property rights that emerged in the nineteenth century provided a fortress of protections for individual rights, but the consequences for collective welfare were quickly found wanting. These consequences were addressed by the welfare state, regulation, and the separation of new spheres of private law such as consumer law and labour law from mainstream doctrine. By the second half of the twentieth century, however, these regulatory measures had triggered a marked shift in private law reasoning as a whole, which became more instrumental or policy oriented. It evolved into a hybrid of the old private interest reasoning and modern policy oriented regulatory reasoning. At extreme moments, common law reasoning was almost reduced to a variant of economic reasoning concerned with maximizing wealth. In reaction, what is happening now is the search for ways to rebalance the underlying values of utility and rights. The task is to construct a legal language through which private law can be reoriented in ways which both give full weight to a wide range of individual rights and at the same time serve collective interests. The increasingly popular method for achieving this task involves the constitutionalization of private law. By grounding the principles of private law in the general principles and abstract rights found in constitutions, it is hoped to restore the balance between utility and rights. Yet this approach requires new techniques for transforming the content of constitutional principles and civil liberties. These public law principles need to be reinterpreted so that they make sense in the context of the relations between private citizens. Furthermore, these public law rights need to be extended into the social, economic, and cultural sphere, so that they can address the questions of distributive justice that the discourses of civil liberties leave unanswered.
\end{abstract}

\footnotetext{
* Professor of English Law, Head of Department of Law, London School of Economics. This essay is a revised version the Horace E Read Memorial Lecture presented at Dalhousie Law School on 22 March 2007. Thanks for their comments and questions are due to members of the faculty and students at Dalhousie and also to V. Mantouvalou.
} 


\section{INTRODUCTION}

This paper offers an interpretation of the present character of legal reasoning in private law. Drawn with broad brush, my remarks offer a description of legal thought in the common law of contracts, torts, and property at the beginning of the twenty-first century. My interpretation concentrates on some tensions that may be detected in contemporary private law discourses and emphasises possible future directions of evolutionary developments in the methods of legal reasoning.

My subject is therefore not a particular topic in private law, but rather it concerns how private lawyers think about legal questions. For this purpose, I assume that legal reasoning in private law shares broadly similar characteristics, whether the issue may be analysed within the categories of contract, tort, property or some other classification. The examples used range over a number of these categories, though plainly these few instances of legal reasoning in English law cannot provide a properly representative sample of reasoning in private law even within one jurisdiction, let alone across many different jurisdictions. Without denying that there are likely to be significant differences between the different parts of private law and between jurisdiction, my contention is that, at least at the level of general evolutionary patterns, it is helpful to regard private law as a whole as comprising a distinct subsystem of the law, with its own logic or particular discourse. In the language of systems theory, my topic is about how private law thinks about issues at the beginning of the twenty-first century and how this communication system is likely to evolve. ${ }^{1}$ I prefer to call this endeavour an interpretation rather than a description, because what interests me most is not the history of the evolution of legal reasoning in private law, but rather its potential evolutionary trajectory. By understanding the tensions and dynamics of the present, we can perhaps glimpse what the future may hold.

Through such studies as this interpretation, we can hope to develop an understanding of contemporary forces that have a bearing on the evolutionary trajectory of reasoning in private law. Yet the path that the law will eventually take remains contingent on choices between different routes forward and on how lawyers respond to the variety of pressures to which the legal system is exposed. My lecture contains a normative message with regard to the question of what should be the response to the contemporary predicament of reasoning in private law. This manifesto is concerned with the relation between human rights law and private law: on the interaction between fundamental rights, as declared in bills and charters of rights, and the everyday laws of contract, tort and property rights.

In a nutshell, my argument is that private law, having been reconfigured in the twentieth century towards a more open-textured, policy-oriented form of legal

\footnotetext{
${ }^{1}$ For discussion of branches of law viewed as communication subsystems: H. Collins, 'Productive Learning from the Collision between the Doctrinal Systems of Contract and Tort' (1997) Acta Juridica 55; H. Collins, 'Legal Classifications as the Production of Knowledge Systems' in P. Birks (ed), The Classification of Obligations (Oxford: Clarendon Press, 1997) 57-70. The terminology is derived from systems theory: G. Teubner, Law as an Autpoietic System (Oxford: Blackwell, 1993).
} 
reasoning, must now seek to rebalance its treatment of individual interests and collective goals, or, in the words of my title to rebalance considerations of utility and rights, by incorporating human rights discourses into private law. In making this argument, I reject a number of other possibilities, ranging from proposals to rediscover natural law foundations for private law rights to those that seek to reduce private law reasoning to a cost/benefit calculus. Yet my argument does not support a simple incorporation of human rights discourses into private law in the manner sometimes described as the 'constitutionalization of private law'.' Instead, it is suggested that a method must be found to translate public law ideas of rights into a form and content suitable for reasoning in private law. This method may be better described by the terms inter-textuality or inter-legality.

\section{THE INTEGRITY OF PRIVATE LAW}

Private law delivers on the liberal state's promise to respect the freedom of individuals. Protection of civil liberties through public law secures for citizens freedom from the misuse of state force. This public law provides negative freedom for individuals. In contrast, private law enables members of the society to use this freedom in constructive ways - to make a home, to earn an income from business activities or a job, and to acquire possessions and enjoy services. The regulatory mechanisms, institutions, and facilitative rules of private law - the rules of contract law, property rights, and rules that protect personal interests against infringement by other individuals - enable personal liberty to become a fruitful experience. Private law constructs a framework of opportunities for individuals in co-operation with others to become authors of their own lives. ${ }^{3}$ In short, private law assists individuals to enjoy positive freedom.

To deliver on this promise of effective and meaningful positive freedom or the opportunity to use freedom to achieve well-being, private law must necessarily construct a legal edifice that emphasises individual rights as well as rules and standards for conduct. To be valuable, to be enabling rather than constraining, this positive freedom cannot be subject to extensive government controls.

\footnotetext{
${ }^{2}$ E.g. C. Starck, 'Human Rights and Private Law in German Constitutional Development and in the Jurisdiction of the Federal Constitutional Court', in D. Friedmann and D. Barak-Erez (eds.), Human Rights in Private Law (Oxford: Hart Publishing, 2001); O. Cherednychenko, 'The Constitutionalization of Contract Law: Something New under the Sun?' (2004) 8:1 Electronic Journal of Comparative Law, http://www.ejcl.org/81-3.hmtl; M. Hesselink, The New European Private Law (The Hague: Kluwer Law International, 2002) 179-184; M. Kumm, 'Who is Afraid of the Total Constitution? Constitutional Rights as Principles and the Constitutionalization of Private Law' (2006) 7(4) German Law Journal 341; H. Schepel, "The Enforcement of EC Law in Contractual Relations: Case Studies in How Not to "Constitutionalize" Private Law' (2004) 12 European Review of Private Law 661; A.C. Ciacchi, "The Constitutionalization of European Contract Law' (2006) European Review of Contract Law 167.

3 J. Raz, The Morality of Freedom (Oxford: Clarendon Press, 1986) describes extremely well the kind of freedom or autonomy which private law (as well as public law) supports, with both negative and positive aspects.
} 
Governments can and must set outer limits to freedom of contract and rights to own property. The law must protect the institutions of civil society from being subverted or abused. But to go further, to review every detail of transactions and private arrangements, in order to assess whether or not they conform to an official view of a good way to live one's life, would be to deny substantially the original promise of the liberal state of supporting positive freedom. If people want to spend large sums of money to watch young men fighting on an ice rink, that is their business, their choice about how to exercise their positive liberty, no matter how pointless or distasteful being such a spectator to organised brawling may seem to others. To ensure that the exercise of positive freedom is not subject to official administrative review at every turn, private law is constructed as a system of rights or entitlements. The rights symbolise and make concrete the point that the individual can choose independently or autonomously how to exercise positive freedom. The individual's choices about well-being are protected from interference by the state or by other individuals by recognising that these choices involve the exercise of rights such as freedom of contract or the enjoyment of private property.

This framework of legal rights entails a particular style of legal reasoning in private law. Legal reasoning seeks to provide detailed content to the rights by establishing systematic bodies of rules and principles. These legal rules establish the scope of rights and determine how the rights of individuals should be reconciled. Their systematic quality permits lawyers to describe the scheme of entitlements and to determine how gaps in the rules should be filled by reference to the surrounding legal materials. The systematic character of the rules enables lawyers to discern underlying general principles, which are generalisations regarding the structure of the rules.

These systematic and principled qualities of private law reasoning created the possibility for most lawyers to regard this branch of the law as engaging in a form of reasoning or discourse that was quite distinct from questions of politics and of distributive justice. For some, it was even possible to imagine that private law comprised the detailed articulation of natural law principles or natural rights. In other words, the rules of private law were regarded by some lawyers and scholars as the embodiment of an immutable moral scheme waiting to be discovered and articulated. Professors of private law, in particular, were attracted to the prospect of presenting their discipline as the exploration and systematization of the legal rules based on fundamental and immutable moral principles. Often they presented themselves to their students and readers as the priests of a faith in this coherent scheme of natural justice. To write about the law of contracts, torts, unjust enrichment and property rights, all that was required was deep knowledge of the rules and precedents and the ability to think analytically and coherently. It was unnecessary, so these private law scholars believed, to make political or policy judgments when describing or even criticising the law. In cases of uncertainty or difficulty, appeals to coherence, consistency, and fidelity to principle would suffice to resolve the issue, without the need to engage in messy and controversial 
discussions about the social consequences of the rules of private law. In short, analysis and discussion of legal principles could be sharply distinguished from arguments about policy and politics.

These foundations in natural law and natural rights, though useful underpinnings for justifying this interpretation of reasoning in private law, were never essential to its legitimacy and effectiveness. It was possible to insist that private law contained implicitly a coherent scheme of rights and principles, even though this scheme might not correspond to any particular moral or ethical theory. Instead, fidelity to the scheme could be justified as both constituting the necessary respect for prior political decisions to establish stability and social order and as satisfying the need to secure the legitimacy of the legal system by ensuring its coherence and basis in respect for rights. It is this position of respect for 'law as integrity', without being tied to a particular moral theory, which Ronald Dworkin articulates so effectively. ${ }^{4}$

\section{THE COLLECTIVIST TIDE OF THE TWENTIETH CENTURY}

It has been widely noted, however, that during the last half century or more, private law reasoning has not remained strictly faithful to this model of law as integrity. Lawyers and judges have increasingly invoked collectivist considerations in their legal reasoning. These considerations might be described as policy, or social consequences, or efficiency considerations. Whatever the label given to these arguments, their crucial characteristic is that they invoke collective welfare considerations as relevant factors in the determination of private law issues and disputes. No longer is private law confined to questions of principle and individual rights. Lawyers and judges began to argue for a particular legal conclusion by reference to the desired outcome for the community or society as whole from the possible different rulings.

Consider one well-known example of this phenomenon: McLoughlin v O'Brian. ${ }^{5}$ The issue in the case concerned recovery in the tort of negligence for personal injuries. These took the form of emotional shock suffered by a mother on seeing her husband and four children in hospital a few hours after they had been gravely injured or killed in a car accident. Following some not entirely clear precedent decisions, the trial judge had denied recovery for emotional shock to the mother on the ground that she had not been present at the scene of the accident. The Court of Appeal upheld this decision, but it was reversed by the House of Lords. In both of the appeal courts, several of the judges not only considered the precedents and general principles of the law of negligence but also assessed what

${ }^{4}$ R. Dworkin, Law's Empire (London: Fontana, 1986).

${ }^{5}$ [1983] 1 AC 410, HL, reversing [1981] QB 599, CA. 
they called policy considerations. They considered, for instance, whether permitting liability in this case might have adverse consequences for the community as a whole. There was the risk that recovery in this case might open the 'floodgates of litigation' or encourage fraudulent claims. More certainly, recovery in this case would increase the cost of liability insurance, which would make it more expensive for everyone to drive cars and might exclude an even larger section of the community from being able to afford to drive at all. Although ultimately these policy considerations were not regarded as sufficiently strong to deny recovery, for many of the judges and lawyers involved in the case there is no doubt that these policy considerations played a vital role in the legal reasoning.

In Dworkin's discussion of this case, he seeks to show how it should have been decided according to considerations of principle in line with his model of law as integrity. ${ }^{6} \mathrm{He}$ approves the approach of the minority of the judges who emphasised the need to respect the principles of the law of negligence, especially the principle that there is a right to compensation for reasonably foreseeable emotional and physical injuries that are the consequence of careless conduct. $\mathrm{He}$ disapproves of an approach that would have reduced the issue to an economic question of which ruling would diminish the over-all cost of accidents. It is clear, though, that a majority of the judges followed neither of these approaches. They used both Dworkin's approved method, seeking for coherence in principle, but they also embraced a collectivist stance, in which they assessed the potential negative consequences for the community of applying the legal principles. The majority of the judges employed both arguments of principle concerned with the rights and interests of individual and arguments of policy regarding collective welfare.

It is this combination of arguments of principle and policy, or arguments about rights and utility, which became characteristic of private law reasoning in the second half of the twentieth century. What caused this change? If we can understand the source of change, we may perhaps better understand the dynamics of this style of reasoning and how it is likely to evolve.

It is true, of course, that the image of private law as a coherent system of principles has been subject to a series of damaging intellectual challenges in the twentieth century. Perhaps most prominent among the scholarly attacks were the critiques presented by the American Legal Realist Movement. As is well-known, these scholars insisted on a sceptical position with regard to legal reasoning. They maintained that judges decided cases according to policy considerations, particularly the likely social consequences of their rulings, rather than applying rules or principles to the case at hand. Rules and facts could always be manipulated to achieve the preferred result. From the Realist perspective, legal reasoning was more mystification than a tool of practical reason. These ideas could be taken further, as they were by the Critical Legal Studies Movement, to

${ }^{6}$ R. Dworkin, Law's Empire (London: Fontana, 1986), 238-250. 
insist that legal reasoning always involved significant political choices because the underlying principles were indeterminate in meaning and contradictory in values.

Although these ideas of the Legal Realists and the Critical Legal Studies Movement indubitably influenced the way in which some legal scholars described and taught topics in private law, especially the law of tort, in my opinion their scholarly efforts were not particularly influential in the mainstream courts and the bulk of private law writing. Legal reasoning in contract law, property, and tort predominantly retained its traditional rhetoric of individual rights, as articulated through rules and principles. Students of contract law usually learn today about the rules of offer and acceptance, of consideration, and the other doctrines that comprise the subject as if the old ideas about private law being an immutable scheme of rights were largely true. Judges continue to insist that questions of principle and their application to particular circumstances are central to the task of adjudication in private law. The sceptical attacks on legal formalism presented puzzles and challenges for private law reasoning, but never dislodged the claims of integrity from their central position in legal discourse. In my view, another influence on private law was far more significant in subverting the traditional paradigm of a coherent body of principles.

This disturbing influence emanated from what today in the common law world we call 'Regulation' or social and economic regulation, though it has other names as well such as 'Social Law' or 'Droit Social'. ' This regulation was enacted by legislatures and developed by administrative agencies with the explicit aim of revising the operation of markets to achieve better consequences for society as a whole. Regulation did not usually replace private law. Instead, it attempted to reverse some of the consequences produced by private law rules and principles. In some instances, such as labour law, regulation was extensive, with the consequence that in many countries the regulation effectively replaced private law rules for most workers. In other instances, such as consumer protection measures, the rules achieved marginal adjustments. In the case of unfair terms in standard form contracts, for instance, regulation typically invalidated certain kinds of particularly onerous terms without challenging the underlying private law principle that standard form contracts are legally enforceable despite the informational asymmetries.

Recent American accounts of regulation emphasise a narrower role for such measures: to address externalities of private transactions. ${ }^{8}$ An example is pollution, which, owing to the difficulties of co-ordinating an effective market response from all those adversely affected by pollution, is, according to this American perspective, a proper subject for regulation. In this account, regulation seems to be justified solely by reference to the failure of an effective market to emerge rather than to correct the outcomes of a market whether or not it is defective. This

${ }^{7}$ L. Duguit, Le Droit Social, le Droit Indivuel et la Transformation de l'Etat (Paris: Alcan, 1908); G. Gurvitch, L'idee du Droit Social (Paris: Sirey, 1932); F. Ewald, 'A Concept of Social Law', in G. Teubner (ed), Dilemmas of Law in the Welfare State (New York/Berlin: de Gruyter, 1988) 40.

${ }^{8}$ E.g. S. Breyer, Regulation and its Reform (Cambridge Ma: Harvard University Press, 1982). 
narrower account of the role of regulation runs hand in hand with some justified, though in my opinion exaggerated, ${ }^{9}$ scepticism about the power of regulation to reverse the outcomes of markets. It is questioned, for instance, whether consumer protection measures really help consumers, or merely induce traders to find more ingenious methods of evading risks whilst increasing prices and harming consumers. Or, in other examples, whether rent controls and minimum wages actually increase rents and suppress wages in the long run, thereby creating exactly the opposite effect to that intended by the legislature. ${ }^{10}$ This scepticism about the effectiveness of social regulation leads to doubts about whether such measures should be preserved.

We should not permit these American efforts to minimise the use of regulation today to obscure its profound historical role in shaping economy and society in the twentieth century. Whether misconceived or not, governments attempted in the twentieth century to use regulation to correct distributive outcomes produced by markets, whether or not those markets were defective or failing. Employment law, for instance, sought to provide workers with mandatory protections even though the labour market worked competitively with only minor frictions and problems of information asymmetry. The purpose of this social regulation was mostly to reverse the outcomes produced by private law. Freedom of contract produced terms of employment that seemed to construct brutal hierarchies and opportunities for exploitation. Employment regulation responded in various ways: by setting minimum standards, by providing protection against abuse of power in the workplace, and by enabling workers to improve their bargaining power in the market. This social regulation was not primarily correcting market failure, ${ }^{11}$ but deliberately reversing the outcomes produced by the system of rights established by private law. It challenged the implicit values and ideology of the system of private law by curtailing its positive freedoms for what were perceived as more important social goals, such as distributive justice and fairer opportunity.

In the course of reversing private law in many contexts, this social regulation presented an implicit challenge to the way private lawyers conceived of their subject. My contention is that the presence of this social regulation has had an unsettling effect on legal reasoning in private law. Lawyers and judges could not ignore the omnipresence of these separate legal schemes of rules that functioned as a further layer of normative standards. Even in cases where no special regulation applied, the courts were tempted to adopt similar patterns of reasoning when developing the common law. In the law of contract these pressures became

\footnotetext{
${ }^{9}$ H. Collins, Regulating Contracts (Oxford: Oxford University Press, 1999) Chapter 11.

10 For a useful summary of the problems of regulatory backfiring: C. Sunstein, 'Paradoxes of the Regulatory State' (1990) 57 University of Chicago Law Review 407, 423: 'In sum, redistributive regulation will have complex distributive consequences, and the group particularly disadvantaged by the regulation will typically consist of those who are already most disadvantaged'.

11 Though certainly some labour law measures could be justified on grounds of market failure: H. Collins, 'Justifications and Techniques of Legal Regulation of the Employment Relation', H. Collins, P. Davies, R. Rideout (eds), Legal Regulation of the Employment Relation (London: Kluwer Law International, 2000$) 3$.
} 
evident in the 1960s and 1970s, when the courts began to consider the protection of consumers as an appropriate role for private law even in the absence of relevant social regulation. In tort law, the social policy ambition of providing a method for compensating every individual who suffered personal injuries in accidents, first represented in special statutes regarding the workplace containing workmen's compensation schemes, gradually infused the application of the law of tort to a wide range of situations where injuries occurred. Lawyers began to discuss the proper scope of the tort of negligence less in terms of rights, fault, and responsibility, and more in terms of securing fair levels of financial support and economic security to all those who had suffered a personal injury resulting from the hazards and accidents of modern living. ${ }^{12}$

In some common law jurisdictions, at some particular moments, the impact of the influence of social regulation on private law reasoning was so strong that it might be fairly said that private law collapsed into some kind of policy analysis. The legal rules and principles were almost completely abandoned in favour of another kind of discourse. Often economic analyses might be presented, but invariably lawyers also paid close attention to factors that economists call 'equity' or lawyers might call fairness, good morals, good faith, reasonableness, or justice. But, in my opinion, those instances where courts and lawyers ignored legal principle and concentrated exclusively on policy analysis were rare.

The traditional legal reasoning of private law was retained in the multiple and persistent references to principles and precedents contained in judgments and legal arguments. In the second half of the twentieth century, what happened rather, in my opinion, was the development of a form of hybrid legal reasoning, which sought to combine the chalk of legal principle with the cheese of policy analysis.

\section{THE CHARACTER OF HYBRID LEGAL REASONING}

The central characteristics of this hybrid type of legal reasoning in contemporary private law are the following. A judge or lawyer engages in an explicit discussion of both the relevant policy considerations and the position regarding rights in legal doctrine. These enquiries into both policy and rights are presented initially as distinct, but when formulating the rule by which to determine the case at hand, the policy considerations are employed to manipulate the evolution of the legal principles. The scope of principles and rights are narrowed or broadened, qualified and supplemented, by reference not to other legal principles but rather as justified by perceptions of the relevant policy considerations. Although framed in the

12 E.g. C. Wright, 'Introduction to the Law of Torts' (1944) 8 Cambridge Law Journal 238; J.G. Fleming, An Introduction to The Law of Torts $2^{\text {nd }}$ edn. (Oxford: Clarendon Press, 1985) Chapter 1; P.S. Atiyah, Accidents, Compensation and the Law (London: Weidenfeld, 1970). 
traditional terms of principles and rules, the consequences of different policy choices are used to determine the exact shape of legal doctrine.

This hybrid reasoning can be observed, for instance, in the leading English case concerning wives as sureties for their husband's business loans, Barclays Bank plc $\mathrm{v}$ O'Brien. ${ }^{13}$ In giving the sole judgment, Lord Brown-Wilkinson presents a section entitled 'Policy considerations', which commences with acknowledging the source of his knowledge about the effects of private law regulation from the large number of cases of this type coming before the courts in recent years'. Having considered this evidence, he describes the regulatory policy in these terms:

It is easy to allow sympathy for the wife who is threatened with the loss of her home at the suit of a rich bank to obscure an important public interest, viz the need to ensure that the wealth currently tied up in the matrimonial home does not become economically sterile. If the rights secured to wives by the law render vulnerable loans granted on the security of matrimonial homes, institutions will be unwilling to accept such security, thereby reducing the flow of loan capital to business enterprises. It is therefore essential that a law designed to protect the vulnerable does not render the matrimonial home unacceptable as a security to financial institutions.

This statement of regulatory policy makes it clear that the objective of providing support to the construction of markets through the enforcement of security must prevail over issues of fairness and justice concerning occupation of the matrimonial home. The judgment then proceeds to examine the preceding case law in order to discover the relevant legal doctrines. As ever, this exercise is selective in its examination of the cases, but it quickly becomes apparent that the selection is not governed by reference to precisely similar cases but rather the judge is looking at a wide range of analogous problems in order to establish some general rules. The outcome of this exercise purports to be the discovery of a relevant principle, the doctrine of 'constructive notice', though it has to be remarked that this principle had not been mentioned in this context in earlier cases. Yet even this claim to be applying pre-existing principle is eventually abandoned when Lord Browne-Wilkinson makes it clear that for the future, whatever their legal duties in the past, the banks should follow certain procedures regarding disclosure of information and fair dealing when entering surety contracts. He imposes a requirement upon banks to disclose information about the nature of the contract, and to give a warning about the need to obtain independent advice. And he defends this requirement not on the ground of precedent but with regard to its suitability for achieving the instrumental objective of upholding these contracts for the sake of the successful operation of the capital market, whilst guarding against the misuse of power within the family. In short, though the decision is presented in the discourses of private law, with its

13 [1994] 1 AC 180. 
references to rights and principles, the evolution of the law in this case is openly determined by economic and social policy considerations.

It may be objected that I am saying nothing new here. It may be said that judges have always considered policy even if they did not mention it explicitly. Of course, that may be true - it is hard to tell. What interests me is the willingness on the part of lawyers to refer explicitly to the policy considerations and use them openly to justify particular developments in the law. My point is not, however, that the policy considerations are mentioned. What is crucial in my argument is, first, that the court feels it necessary to mention the policy considerations in order to provide an adequate justification of its decision, and second, that the court explicitly describes how the policy considerations are the drivers of the evolution of legal doctrine.

In other words, my first point about the character of hybrid legal reasoning is that without the reference to policy, lawyers and judges apparently think today that the legal reasoning would not provide a sufficient justification for a particular decision. In this respect private law becomes similar to regulation in that it must be judged by its results measured by welfare criteria, not just its coherent protection of principles and rights. To put the point more bluntly: a legal decision reached in accordance with strict fidelity to principle that violates important policy considerations which are already reflected in social regulation is now regarded not just as an unfortunate decision but one that is probably a wrong decision in law.

My second point about hybrid reasoning is that, if the court regards it necessary to change or develop the law, though this evolution will be constructed through modifications of legal doctrine, the new shape of the legal doctrine will be justified exclusively by reference to its suitability for achieving the policy goals recognised as relevant by the courts. It is not simply that the court bears policy considerations in mind when developing the common law. The insertion of policy considerations is not done merely to help the judge in weighing up competing principles or rights. It is rather that the policy considerations determine the precise shape of the legal doctrine, the details of the rules, and that this justification by reference to policy is both necessary and sufficient. It follows, of course, that the notion that the judges are discovering the law, or merely developing it according to existing principles, is hard to preserve when, in the course of the judgment, the court is explicitly fashioning the rule in order to achieve a particular set of policy goals. The decision will inevitably look like prospective law-making rather than evolution of existing principle.

Yet, in my view, private law of this hybrid kind does remain distinct from social regulation. Despite the addition of the explicit and determinative references to policy considerations, the commitment to the preservation of a coherent body of principle remains present. Private law becomes rather a kind of hybrid legal reasoning, one which both retains its fidelity to the tradition of rights and principles whilst at the same time seeking replicate the reasoning processes of social regulation. Decisions have to be justifiable by reference to both criteria legal principle and social policy. 


\section{REBALANCING PRIVATE LAW}

The development of a hybrid private law has not gone unchallenged. Reservations are expressed by scholars about the loss of fidelity to principle, the incapacity of judges to perform the complex tasks of policy analysis which they set themselves, and the obliteration of the functional divide between private law and corrective social regulation - or between determinations of rights and administrative policies. For some scholars, such as Ernest Weinrib, the developments in legal reasoning described above violate the essential characteristics of private law, ${ }^{14}$ or, in the words of Nigel Simmonds, represent the decline of juridicial reason. ${ }^{15}$ I do not share those laments for a past and perhaps mythical age of pure private law.

In my view, private law must always struggle with the endeavour of how to cope with the competing concerns of individual and collective interests. It can never limit itself to an examination of individual rights and corrective justice between two individuals. It must always have regard to collective interests, to the distributive patterns produced by its rules. Take as an example, the problem of claims of workers who suffer from mesothelioma (a rare form of lung cancer caused by exposure to asbestos), but who are unable to prove which of several their past employers was responsible for introducing the harmful dust into their lungs. To look at this issue solely in terms of individual rights, responsibility, causation and fault, seems destined to produce the result that the worker cannot obtain compensation from anyone on the ground that it is impossible to prove who caused the illness or who is at fault. What that framework of analysis lacks is the more collective perspective that emphasises the objective of securing compensation or economic security for workers who are injured through no fault of their own and the possibility of achieving that goal through some form of collective insurance. As in the recent decision of the House of Lords in Fairchild v Glenhaven Funeral Services Ltd, ${ }^{16}$ contemporary courts are likely to favour workers in these instances, no doubt sometimes at the expense of fidelity to existing legal doctrine, in order to achieve the social goal of compensation by using the tort system and liability insurance as the mechanism. In this instance, a court is necessarily balancing individual interests against collective social policies. In my view it is right that it should do so. It is wrong to assume that collective social policies will always be secured by fidelity to existing legal principles based upon individual rights and corrective justice. That would be as foolish as to assume that the free market always achieves welfare maximisation.

On the other hand, as mentioned at the beginning, the great strength of private law, as opposed to other branches of the law, has been its recognition that to achieve positive freedom and the consequent well-being that benefits from that freedom, the starting point of the law should lie in individual rights and the protection of individual interests. There is certainly a danger that the hybrid

${ }^{14}$ Ernest J Weinrib, The Idea of Private Law (Cambridge and London, 1995).

${ }^{15}$ N.E. Simmonds, The Decline of Juridicial Reason (Manchester: Manchester University Press, 1984).

16 [2002] UKHL 22; [2003] 1 AC 32. 
version of legal reasoning that has come to the fore in recent decades might lose sight of this crucial insight that formed the foundation of the systematic development of private law in the nineteenth century. To that extent, the critics of the use of policy arguments in private law have a valid point.

Yet, I do not believe that the way forward in private law reasoning is to revert to the exclusive use of narrow doctrinal argument. That would betray the achievements of the twentieth century in acknowledging explicitly that private law must simultaneously look both to the individual interest in positive freedom and the collective interest in securing general welfare, recognising that sometimes these considerations will exist in tension with each other.

Instead, I suggest that to the extent that a rebalancing between the collective and individual interest may be required in the reasoning processes of private law, it can be achieved by the means of inserting fundamental rights discourse into private law as another layer in the reasoning process. This process, which is known in Germany as the 'constitutionalization of private law', involves private law reasoning directly engaging with the norms or standards of the discourses of constitutional rights and liberties. Shortly, we will need to consider carefully exactly how this relation between public law rights and private law reasoning should be understood and developed. But the important point to grasp in my argument is not so much the precise details of the linkage as the purpose of expanding private law reasoning in this direction.

My central argument is that the resort to fundamental rights should be understood as a mechanism for adding to the complexity of private law reasoning for the purpose of placing a check on the inherent tendency of contemporary hybrid reasoning to pursue policy considerations at the expense of considerations of private autonomy or positive freedom. In the case regarding asbestos, for instance, the reasoning of the House of Lords starts with the principles of causation and a close examination of the authorities. It then moves to policy considerations with a view to revising those principles in order to construct an exception that will secure the goal of compensation for the workers and their dependents. In these respects, the case illustrates well the standard practices of hybrid reasoning in private law. The introduction of a final stage in the legal reasoning of the court, comprised of references to human rights and civil liberties, would test that conclusion against these fundamental values. The question for the court would be whether or not a judgment in favour of the workers would violate or interfere with the fundamental rights of employers or some other citizens. If such a right were unjustifiably interfered with by the proposed ruling, such as the right to a fair trial or the right to peaceful enjoyment of property, that interference would provide a sufficient reason for blocking the ruling envisaged under the hybrid reasoning governed by policy considerations. In the absence of a material interference with rights, however, the evolution of private law produced by hybrid reasoning should be respected. If material interference with rights is discovered, that would not necessarily mean that the ruling produced by hybrid private law should be rejected. The important question would then become whether or not 
the material interference was either disproportionate or discriminatory. If the interference was found to be proportionate to the aims and avoided unjustifiable discrimination, it could still be upheld.

\section{INSERTING HUMAN RIGHTS DISCOURSE IN PRIVATE LAW}

In the previous paragraph, I employed numerous technical terms, such as proportionality, which are perhaps rather more familiar to those versed in European Human Rights law and European constitutional discourses, though I am sure that the underlying ideas concerning levels of judicial scrutiny over legislative and executive acts are recognisable to most lawyers. In order to help elucidate these terms and their significance here, let me illustrate this model of reasoning in private law that encompasses references to human rights, that is, the constitutionalization of private law, with an English case which was ultimately called Wilson $v$ Secretary of State for Trade and Industry (No 2). ${ }^{17}$

The contract in this case involved a six months loan of about f,5,000 to Mrs Wilson by a small lending bank known as First County Trust Ltd. She gave as security for the loan her BMW car. When she failed to repay the loan on the due date, the bank proposed to recover the debt, which by then stood at nearly $£ 7,500$, by selling the car. Mrs Wilson's legal representatives persuaded a judge to use powers under the Consumer Credit Act 1974 to reduce the interest rate on the ground that at $94.98 \%$ it was 'grossly exorbitant' and therefore 'extortionate' within the meaning of sections 137-138 of the 1974 Act. The interest rate was substantially reduced by the court. Mrs Wilson repaid the loan at the cost of $£, 6,900$ and recovered her car. But there remained one outstanding issue concerning the validity of the original written loan document. On appeal, the Court of Appeal decided that the documents that comprised the loan agreement included a small error in the statement of the amount of the loan or the 'amount of credit'. 18 The effect of that error under section 127(3) the Consumer Credit Act 1974 was that the court could not enforce the contract against the debtor. If that conclusion was correct, Mrs Wilson could recover all her money back, that is, the $£^{6,900}$ (plus interest at $8 \%$ ), because technically the bank had never had the right to sue her at all under the statute.

At this point, the Court of Appeal asked whether this result involved a material infringement of the Human Rights Act 1998, which is the legislation that incorporated the European Convention on Human Rights and Fundamental Freedoms into the law of the United Kingdom. The Court of Appeal concluded, after a rehearing, that it did constitute a material infringement of human rights. The bank's right to the peaceful enjoyment of its property was violated, and so too

17 [2003] UKHL 40; [2004] AC 1 AC 816

18 Wilson v First County Trust Ltd [2001] QB 407, CA. 
the bank's right to a fair and public hearing before deprivation of its rights, as demanded by Article 6 of the European Convention of Human Rights, had effectively been restricted. These interferences with the rights of the bank could only be justified if they satisfied the test of proportionality. The Court of Appeal reached the further conclusion that the interference was disproportionate, with the upshot that section 127(3) of the Consumer Credit Act 1974 was declared incompatible with fundamental rights, and the bank was entitled to retain its $f, 6,900$ plus costs. ${ }^{19}$

In order to defend the statute and its protection for consumers, the Secretary of State launched a successful appeal to the House of Lords. The precise ground for the decision was that the Human Rights Act 1998 did not have retrospective effect, so could not apply to transactions entered into prior to its coming into effect in 2000. On the substantive points, however, the House of Lords offered the opinion that indeed there was a material interference with the right to peaceful enjoyment of possessions. Nevertheless, the judicial committee agreed unanimously that the statutory ban on defective consumer credit agreements was justifiable because it satisfied the test of proportionality. In one of many observations of this type in cases involving the Human Rights Act 1998, ${ }^{20}$ the judicial committee exhibited strong deference to the judgment of Parliament on the issue of proportionality, whilst retaining an oversight to intervene in some instances.

Although this decision involves a statute, which might be regarded as more in the category of regulation than private law, it serves to illustrate the three dimensions of private law reasoning that $\mathrm{I}$ am arguing have become a necessary and appropriate response to the evolution of hybrid private law. The underlying traditional private law respects the contractual and property rights of the parties: the bank is entitled to enforce its bargain, but the debtor is entitled to the return of the security once the debt has been repaid. Layered on top of this private law regime is a statute that seeks to pursue various policies with respect to the protection of consumers who get into debt with unscrupulous moneylenders. Although the common law had provided some protection through equity, it had proved inadequate in the context of the expansion of the consumer credit market. This regulation revised the private law rights both to deprive the moneylender of the right to enforce extortionate interest rates, and to require transparency in the paperwork, so that the consumer might at least have the chance to understand the essential framework and details of the transaction. These statutory provisions, in general, give a court considerable discretion to rewrite the bargain, as happened in the Wilson case in respect of the interest rate. In the case of material inaccuracies in

19 Wilson v First County Trust Ltd (No 2) [2001] EWCA Civ 633, [2002] QB 74, CA.

${ }^{20}$ E.g. Lord Chief Justice Woolf, It is ...important to have in mind that legislation is passed by a democratically elected Parliament and therefore the courts under the Convention are entitled to and should, as a matter of constitutional principle, pay a degree of deference to the view of Parliament as to what is in the interest of the public generally when upholding the rights of the individual under the Convention.' R. v Lambert [2002] QB 1112, CA, para. 16; cf C. Gearty, Principles of Human Rights Adjudication (Oxford: Oxford University Press, 2004) Chapter 5. 
the written document, however, rectification was not regarded as an adequate remedy for the consumer, so Parliament provided for the nuclear option of depriving the creditor of any legally enforceable rights at all. The final layer of the analysis questions whether this hybrid structure that pursues a mixture of private economic rights and social policies does so in a way that disproportionately interferes with those basic rights of citizens, which are typically found in constitutional documents. It was this final question that the House of Lords addressed when it concluded that the bank's inability to enforce the transaction, though a material interference with a fundamental right, was not an inappropriate and disproportionate way of pursuing the legitimate goal of consumer protection.

In conducting this final layer of the legal analysis, the court has the opportunity to consider whether the hybrid reasoning of private law has lost touch with the underlying objective of providing a space for private ordering, for permitting individuals to organise and enjoy their own lives, without having to seek approval of the government or having to conform to rules about how one should lead one's life. In essence, the Consumer Credit Act 1974 states that one should not be permitted to lead the life of an unscrupulous money lender, who charges the poor and needy extortionate rates of interest, whilst disguising what one is doing behind misleading documents or even avoiding any paper records at all. The reference to human rights law enables a court to ask whether this interference with a chosen way of life, namely the one of unscrupulous moneylender, is disproportionate in the light of the damage caused by these activities to the poor and needy. This final step in the enquiry is necessary to ensure that private law can continue to achieve its basic objective, which I have described as facilitating the enjoyment of positive freedom.

\section{INTER-TEXTUALITY}

Having asserted the need for this human rights corrective to hybrid reasoning in private law, I want to insist on some more detailed structures for this turn in private law reasoning to serve the aim of rebalancing private law reasoning. There are three essential points to bear in mind.

\section{SEPARATE SPHERES}

The first proposition is that I am not suggesting that private law should be incorporated into a single edifice or structure for the law with constitutional rights at its apex. On the contrary, it seems to me important to preserve the division between public law and private law in our thinking. We should not require that one branch of the law should judge its validity by reference to the standards of the other. We should no more determine the validity of every private law rule by reference to public law principles than we should test every administrative action 
of government to see if it satisfies exactly the laws of contract, property, and tort. There are good reasons why the law has evolved distinct functional subsystems such as public and private law. These different branches of the law have coevolved with different types of human activity. The rules and normative standards have been developed separately to solve the distinct co-ordination problems and risks of abuse of power.

The new task, as I envisage it, is to protect the fundamental values of private law, not to impose other values on it, no matter how much we may respect those values. But those fundamental values of private law, especially with regard to their concern for the realisation of positive freedom, also provide part of the motivation for the human rights standards of public law. It is likely, therefore, that we will find considerable overlaps in the rights or norms that we should consider.

The German terminology of the 'constitutionalization of private law' is therefore unsatisfactory, as it implies that somehow private law is being subsumed within constitutional law. This notion, which is accurately described by Mattias Kumm as a 'total constitution' in which private law is 'a branch of applied constitutional law', ${ }^{21}$ is not what is being proposed here. It is important in my view to preserve the separation of private and public law, since both aspects of law have co-evolved with their respective spheres of social life - civil society with private law, and relations between citizen and the state with public law. The separation of the subsystems of public and private law evolved in response to the correct perception that they were handling different kinds of conflicts and co-ordination problems. It will not work to force the subsystems back together again, with one having priority over the law. Nevertheless, for the reasons I have given, it is necessary to re-establish a conversation between the rights discourse of public law and private law in order to provide a safeguard against potential unsatisfactory developments in contemporary hybrid reasoning in private law.

\section{Private Law Conceptions of Human Rights}

The second proposition follows from this preservation of the separate normative subsystems of public law and private law. Although these dimensions of the legal system may share many common general principles in the sense of respecting ideas of freedom and autonomy of individuals, we should expect that in the meaning attributed to these fundamental rights, there will emerge significant differences between private law and public law. With respect to freedom of expression or freedom of the press for instance, in public law in a liberal society we are likely to regard any attempt at prior restraint on publication by the government with considerable suspicion. We must doubt the legitimacy of the state seeking to restrict the dissemination of any ideas and information without the most compelling justifications such as national emergency or national security.

${ }_{21}$ M. Kumm, 'Who is Afraid of the Total Constitution? Constitutional Rights as Principles and the Constitutionalization of Private Law' (2006) 7(4) German Law Journal 341, 359. 
With regard to freedom of expression in private law relations, however, the meaning of the concept must alter because in this context we are concerned with the relations between private citizens. Freedom of expression must be respected even in these private relations, but it must be balanced against other interests such as damage to reputation and the right to uphold contractually agreed limits on that freedom as in the case of confidentiality clauses.

To make this point in a more technical way, the task of rebalancing hybrid legal reasoning with references to human rights is not the same process as to give indirect horizontal effect to constitutional rights in private law. Indirect horizontal effect would imply that private law is being required to conform to the standards of constitutional law adjudication. The application of this concept of indirect horizontal effect would suggest that courts when applying any aspect of the law, including private and commercial law, should always observe public law rights because they are binding on everyone, including the courts, in every task they perform. This would render human rights standards an implied term of every contract, or a determinant of the duties of care in tort. It would be to transplant public law concepts wholesale into private law doctrine.

I think that such an approach would be to misunderstand the task facing the courts. It is not indirect horizontal effect or a transplant that is required, but rather 'inter-textuality' or 'inter-legality'. ${ }^{22}$ The values found in expressions of rights in constitutional documents need to be translated into concepts and principles that fit into the structures and coherent principles of private law. The two parts of the law, private law and public law, need to be normatively compatible, whilst not expressing and articulating those principles and rights in the same way.

Let me illustrate what this idea of inter-textuality means by considering an example where the court failed to do what I am suggesting it should, and instead followed the route of indirect horizontal effect. ${ }^{23}$ The case concerned a probation officer, Mr Pay, who was employed to help criminal offenders, including those convicted of sexual offences, to return to the community. On weekends and in the evenings, outside working time, he ran a small business selling goods used in sadomasochistic practices - whips, chains, and leather outfits mostly. He sold these items at clubs and on the internet. Even though this business was entirely lawful, his employers gave him an ultimatum that he should either give up his business or be fired. He chose the latter course and brought a claim under UK law for compensation for unfair dismissal. ${ }^{24}$ The court accepted the general proposition that I have been presenting: in order to determine the lawfulness of the dismissal, the court agreed that it was relevant to consider whether or not Mr Pay's fundamental rights had been violated. A dismissal could not be fair if it amounted

22 The terminology of 'interlegality' derives from theories of legal pluralism, where it seeks to explain the types of communication possible between autonomous legal orders that operate within the same territory, where neither has a hierarchical relation to another, but it can be applied to complex federal-like legal orders such as the European Union: M. Amstutz, 'In-Between Worlds: Marleasing and the Emergence of Interlegality in Legal Reasoning (2005) 11 European Law Journal 766.

23 Pay v Lancashire Probation Service [2004] ICR 187, EAT.

${ }^{24}$ Employment Rights Act 1996, s.93. 
to an unjustifiable interference with fundamental rights. What fundamental rights had been violated? The court accepted that the employer had interfered with fundamental right to freedom of expression, but it held that the employer's desire to protect its reputation was a legitimate goal to pursue and that dismissal of the employee was not a disproportionate means by which to secure that goal. With regard to the right to privacy, the right to have one's private and family life respected, however, the court said that there was no material interference with the right at all. Mr Pay conducted his business in public, in the full glare of the internet worldwide, not in private, so that the right to respect for his private life was not engaged.

This legal reasoning uses the method of indirect horizontal effect or transplant. It employs the meaning of the right to privacy that has been established in public law and constitutional law cases, such as those involving police surveillance of people in their homes or when making telephone calls. The decision then applies this conception of the right to privacy directly to the private law context of a contract of employment. The problem with that reasoning is that it ignores the substance of Mr Pay's claim: he is arguing that what he does in his spare time, provided that it is legal, is none of his employer's business. To discipline an employee for his hobbies and past-times conducted outside working hours is, on Mr Pay's argument, a material interference with his private life. The court is applying the wrong conception of the right to privacy to the case. It is using a public law concept in a private law context. This error arises from using the method of indirect horizontal effect. In contrast, a reasoning process based on the method of inter-textuality does not directly import legal concepts and their meaning from another branch of the law. Instead, it translates the underlying concept, such as the right to privacy, into principles which interpret the idea in a way that fits into and makes sense within the context of private law.

In the new context of a contractual relation, the meaning of the right to privacy must be reconstructed in order to express the relevant features of this ideal to this private relation. In most contractual relations it should not be relevant to that relation what the parties are doing when they are not performing the contract. Contracts create an autonomous, limited commitment, as defined by the terms of the contract. Aside from insurance contracts and some fiduciary relations, contracts do not require utmost good faith or loyalty to the other's wishes or interests outside performance of the contract. This circumscribed quality of contractual commitments creates their utility for realising personal freedom. The other side of the coin must be that events that occur outside the performance of the contract should be regarded as irrelevant, as private matters. In my view $\mathrm{Mr}$ Pay was correct to argue that his right to privacy was engaged by his dismissal. Possibly an employer might be able to justify termination of the contract as a proportionate and necessary response in pursuit of a legitimate aim such as protection of business reputation. But this issue of justification was not reached in this case, because the court used the method of indirect horizontal effect. It applied the constitutional law concept of fundamental rights instead of an inter- 
textual approach, which would translate these ideas of fundamental right into a conception that makes sense within the system of private law.

\section{SOCIAL RIGHTS}

My third proposition concerns the range of rights. A contrast is often drawn between civil and political rights, on the one hand, and social and economic rights, on the other. The former are commonly given full legal force in constitutions and bills or rights, whereas social and economic rights such as the rights to education, health care, and to decent work, are usually stated as mere aspirations or not even mentioned at all in national constitutions, though they are proclaimed in numerous international conventions such as the United Nations International Covenant on Economic, Social and Cultural Rights of 1966.25 Without entering into the debate about whether or not this division between the categories of rights has coherent intellectual foundations, we do need to address the question of the relevance of social and economic rights to the proposed process of inter-textuality. When a court applies the final stage of the reasoning process, in order to assess whether the result produced by hybrid reasoning is compatible with the fundamental values expressed in the ideas of human rights, should those values or rights also include social and economic rights?

The case for adopting a broad scope of rights and for including social and economic rights is linked to the origins of hybrid reasoning itself. Social and economic rights can be viewed as the values that underpin the regulatory interventions of the twentieth century, which in turn, as I have argued, produced the evolution of hybrid reasoning in private law. Social and economic rights can be viewed as a modern way of expressing the collectivist values that were formerly described in the language of utility and welfare. The point of describing these values as rights is to both to reinforce their importance as political values and to promote a more egalitarian distribution of those benefits. In the case of the right to shelter or housing, for instance, the goal of collective welfare will undoubtedly be promoted if everyone manages to obtain a decent home to live in; by describing this value as a right, the point is made that every individual in society has, in principle, an equal claim to this benefit.

When a court reaches the final stage of reasoning in which the outcome produced by the hybrid reasoning of both principle and policy is tested against fundamental values that protect positive and negative freedom, the emphasis will undoubtedly be placed on traditional civil and political liberties. The central issue is whether a fundamental right will be materially invaded by the proposed ruling, such as to award compensation even in the absence of clear proof of causation by the defendant. In this context, the court will be looking at civil and political rights including the right to peaceful enjoyment of property. If the court is concerned

25 See also: Council of Europe, European Social Charter, 1961, revised 1996; the Charter of Fundamental Rights of the European Union 2000 (C 364/01). 
about the degree of material interference with such a basic right, the next step is to assess whether or not the interference is disproportionate. It is at this stage of justification that social and economic rights are likely to play an important role.

References to social and economic rights will tend to reinforce the justification for the policy dimension of the hybrid reasoning. A social and economic right will provide a legitimate goal and emphasise its importance in the assessment of the justification. In Mr Pay's case, for instance, if the issue had reached the justification stage on the matter of his right to privacy, the court might then have balanced the interest of the employer in its reputation as a legitimate goal against the social right of the worker not to be unjustly dismissed. The worker's social right weakens the strength of the employer's business interest, so that it has difficulty in justifying such a strong response as dismissal to something that in the end, at most, would have been embarrassing to the employer. In contrast, in Wilson's case, it is less clear that the consumer protection measure of rendering the loan unenforceable was justifiable by reference to a social and economic right. The justification for this measure was therefore weaker, on a borderline where one might expect courts to reach divergent opinions.

\section{CONCLUSION}

In conclusion, I am proposing that private lawyers should embark on a project that is misleadingly labelled the constitutionalization of private law. This project, I suggest, is necessary to help to rebalance private law, which risks being diverted from its mission to secure the capabilities to enjoy positive individual freedom as a result of developing a hybrid form of legal reasoning that emphasises the importance of collective interests. Although the inter-textual approach to fundamental rights might not affect the result in many instances of private law disputes, it would, I suggest, secure a rebalancing between the perennial concerns of private law, the competition between individual rights and collective welfare or utility. 